\title{
THE DEVELOPMENT OF PRINCIPLE IN TRESPASS
}

\author{
GEORGE F. DEISER
}

of the Philadelphia Bar

The principles upon which redress is based in the action of trespass are, like all common-law principles for the greater part, the product of historical development. This is more universally true of trespass than of any other form of action because of its wider significance, and because it occupies probably two-thirds of the attention of the modern court. It needs no proof to demonstrate that economic and social change are the controlling factors in the evolution of trespass, and not judicial or philosophical fiat. For example, some years ago a person riding upon the front platform of a street car was not considered to be the agent of his own injury if hurt by misadventure. But suddenly the eyes of the community are awakened to the possibilities of electricity as a motive power, and all street cars are now operated by means of electricity. Straightway the law of trespass responds, and to jurisprudence is added a new principle, namely, that one who stands on the platform of an electric car, when he could have gone inside, has assumed a certain risk, and, if injured, must shoulder the responsibility himself. 1 As this process of adding principle to principle through some fourteen centuries has resulted in that enormous mass of decisions which, added together, constitute the law of trespass, what, if any, theory has been the law of its development? From the year r285 A. D. onward, the history of trespass is an open book in this sense, that the decisions are there available to anyone who chooses to read. From that date the judges administer relief in trespass and in all its allied actions very much as if they had inherited from their forbears certain views or principles of which the relief granted was a necessary corollary. There is, however, no suggestion of any underlying theory unless the general maxim of the common law that no wrong shall be without a remedy can be called a theory. It must be observed in parenthesis that acceptance of the historical method of inquiry precludes a belief in any theory, if anything static be involved in the word theory; for a case decided upon one theory to-day may be decided upon another in the course of a few years or even a few months.

\footnotetext{
${ }^{2}$ Thane v. Scranton Traction Co. (I899) I9I Pa. 249.
} 
The law of trespass chronologically, like that of contractlike that of the entire common law-falls into three distinct periods. The period of no reports, from $566 \mathrm{~A}$. D. to II94 A. D.; the period of the records, to 1285 A. D.; and the period of the common-law reports from that time to the present. There may be common-law reports prior to I285 A. D., for there are many unpublished Year Book manuscripts of the reign of Edward $\mathrm{I}$, but the date $1285 \mathrm{~A}$. D. is chosen arbitrarily as marking the beginning of that peculiar development of trespass which is based upon indirect injury. Although but few reported cases exist as late as the year 1387 A. D., the law of negligence had in that short time progressed so far that in an action of damages for failure to repair a hedge, there is laid a duty, a breach of the duty, and resulting damage. ${ }^{2}$ Thus early, therefore, the basis of redress in trespass on the case, the fundamental principle of universal recognition from that to the present, was established. As the Statute of Westminster II, as interpreted, led inevitably to this decision, and as that statute was introduced to supply a recognized defect in the common law at the time of its passage, the date chosen is not without significance. It is obvious that a remedy already existed for all tangible injuries or trespasses, or rather, for such injuries as were produced by direct causes, and had not to be followed through a chain of causation. It is the purpose of this essay to trace the development of the action of trespass prior to the Statute of Westminster II, and to discover the principles upon which redress was based.

The action of trespass from its origin has been intended to provide a remedy for an injury to property or to the person. In modern terminology it is an action for damages. Was it always so? The damages constitute the remedy. But the trespass in the early law was very frequently the taking of property. Toward what end was the action directed when the injury was an assault?

It will appear in the course of this discussion that the action of trespass existed for the purpose of affording a remedy, and that if damages were sought, or even were involved, they were usually granted. It will appear also, that the action was not criminal in nature, except for the fiction by which the king justified his interference, that the defendant had been guilty of a breach of the king's peace.

In the Saxon period it is hopeless to seek for a distinct law of trespass. And, considered as a judicial system, the Saxon

'Y. B. H, II R. II, Fitzherbert, Accioni sur le case, 36, (19:2) 25 HARr. I. REv. 341. 
Dooms present a colorless picture indeed. Some pretense might be made to evolve from those general miscellaneous provisions a law as to sales, as to warranties, or even as to the collection of debts, but no form of action can be discovered to which the name trespass could be applied.

But if it should be assumed that the Saxon laws afford no evidence that bears upon the subsequent history of trespass, nothing could be wider from the mark. The defect to be observed in those laws is not lack of instances in which trespasses, typical of the tortious wrongs of our own day, may be redressed, but of any legal conception or form of action capable of assimilating a large number of instances, by means of which uniform legal development might have been possible. It is probable that the want of a jury had much to do with the incoherence of the Saxon law. Each provision of the Dooms contained a fixed penalty for an individual act. Classes of acts had no existence; classes of wrongs had no existence. For example, the laws of Aethelbirht exacted the sum of fifty scaetts from the man who pulled his neighbor's hair. ${ }^{8}$ And if a man passed over a fence, he was obliged to pay four shillings." There is no need of multiplying instances of this sort, for the Dooms are filled with them. The moral is plain: There being nobody charged with finding facts and assessing damages, the law of necessity fixed the damages beforehand, with a few exceptions. There were occasions, however, on which the lawgiver must have felt the need in certain cases of leaving some portion of the damages or compensation to be determined by unprejudiced third persons. And a few provisions of the Saxon Dooms justify this conclusion. The law had no difficulty in fixing the amount to be paid if a defendant broke the plaintiff's thigh. With its customary directness the Saxon law said, if a thigh be broken, let bôt be made with twelve shillings. But it was obliged to consider also that a broken thigh might leave the plaintiff lame. - In that case, said the law, the friends must arbitrate. 5 So, too, in the case of injuries the extent of which must be left to the imagination, the amount of compensation was necessarily left indefinite, because it could not be ascertained beforehand.

B. Thorpe, Editor, Ancient Laws and Institutes of England, etc. (1840) I3. I Felix Liebermann, Gesetze der Angelsachsen (I903) 5. A scaett is I/250 of a pound of silver, I Rogers Ruding, Annals of Coinage (I\&40) 296.

Thorpe, op. cit. Ir.

Thorpe, op. cit. xg. Liebermann, op. cit. 7 . 
"If anyone injure another man's vineyard, or his fields or aught of his lands, let him make bôt as it may be valued."

There is nothing to indicate how the inquiry is to be conducted, but the instances quoted leave no doubt that there was some method of fixing damages other than the foresight of the legislator. ${ }^{7}$

The assessment of damages plays a great part in the development of the action of trespass. And as the jury later became the machinery by which this task was performed, we may ascribe no little influence in the history of the forms of action to this source. The Saxon Dooms would not have contained separate provisions for a broken thigh, for pulling hair, and many like offences, had it been possible to leave the extent of the damage and the amount to be paid, to the jury. Without the jury, there might have been no common law, and we might be drinking our legal lore from Roman goblets. This is pure assumption, however, for it can never be known how much common law passed over at the time of the Conquest and by tradition gradually worked its way into legal principle. This is all that can be said of damages in the Saxon law. Of the punishment of offences that might be considered trespasses there is no lack, and they include wrongs of almost every type of trespass known. Let it be understood that they are miscellaneous provisions aimed not at a class of cases but at the particular event. The law was not aimed at wrongs of force in general but at the breaking of an arm by the defendant or the breaking of a fence by cattle.

The reign of Henry II may be regarded as a cauldron into which was poured an unassorted mass of litigation to be fused and alloyed and refined, and by various processes molded into a coherent form. The molds as we know were furnished by Henry II-the jury-the writs-the invitation to suitors, rich and poor alike, to seek justice in the king's court. And in II94 A. D. begin the records, and with them, the principle of stare decisis. ${ }^{8}$

It remains to discover what was contained in that body of law upon which the processes of the common law were to work. Of such trespasses as result from the direct application of forces, little need be said. The Saxon Dooms are built upon force. More than one-half of the law consists of

- Thorpe, op. cit. 54 Liebermann, op. cit. 37.

'See 2 Pollock and Maitland, Hist. Eng. Law, 523.

See Jenks, Short Hist. Eng. Law, 24. 
an enumeration of deeds of violence for which compensation must be made, or for which the king imposes a penalty. At times, as in the case of the broken thigh, the remedy is farreaching and extends to injuries that may develop later. So too, the bôt is twelve shillings if an ear be cut off, twenty-five shillings if, as a consequence, the other ear becomes deaf.10

Although trespass is termed a noxal action, involving something in the nature of a crime, the inception of the action, or rather the first attempts to give compensation for harm due to wrongful acts, suggest nothing that is criminal. The inevitable result of the litigation is the payment of money. It is not until the time of King Alfred that the resounding phrases of the book of Exodus fill the laws with retribution and physical penalties. ${ }^{11}$

The Saxon law was not indifferent to the intention with which an act was done, nor to the element of malice, if present. One who furnishes weapons to those in strife must pay six shillings though no one be injured. ${ }^{12}$ Again, if the owner of an ox know of any viciousness in his beast and neglect to confine it, he must give another $\mathrm{x}$ if his own gore that of his neighbor, whereas if he be ignorant of any evil traits in the animal, the penalty is less. ${ }^{13}$

There are many provisions in the Saxon laws of a similar nature that suggest tests of liability, and some that border on negligence. And if a modern terminology may be applied to a legal system that had no distinctive forms of action, contributory negligence was at times an answer to a claim for compensation.

A churl's close ought to be fenced, winter and summer; if it be unfenced, and his neighbor's cattle stray in through his own gap, he shall have nothing from the cattle-let him drive it out and bear the damage. ${ }^{14}$ If, however, there be a beast that breaks hedges and goes in everywhere and he who owns it cannot or will not restrain it, he forfeits all of the animal except the skin. ${ }^{15}$ And if a man find swine among his mast, he is entitled to six shillings. But if they have been there only once the owner need only pay a shilling if he can prove that they came not there oftener. ${ }^{18}$ Yet why the distinction between straying cattle and straying swine? The penalty for carelessness

'Thorpe, op. cit. 15, par. 39. Liebermann, op. cit. 5, par. 40.

${ }^{20}$ Thorpe, op. cit. I5, par. 40. Liebermann, op. cit. 5, par. 39.

"Thorpe, op. cit.; Liebermann, op. cit., Laws of Alfred.

12 Thorpe, op. cit. 7 . Liebermann, op. cit. 4.

${ }^{13}$ Thorpe, op. cit. 35 . Liebermann, op. cit. 35 .

"Thorpe, op. cit. 127.

${ }^{25}$ Thorpe, op. cit. 129.

${ }^{18}$ Thorpe, op. cit. 133 . 
in carrying a spear might contain a suggestion of negligence, if there were any indication of uniformity in the application of the law. The tests of liability appear sporadically and not as part of any coherent legal consciousness. ${ }^{17}$ Yet tests must have been applied. In the case of the spear the test appears in the law; if the butt is higher than the point, the penalty is so much; if the butt and the point are on the same level, there is no fault. Furthermore, some test must be applied to determine whether or not a man knows of vice in his beasts. But when this is said, all is said. The law progressed, no doubt; for the first reported cases disclose an almost inconceivable advance over this haphazard way. of settling litigation. Yet it is clear that the Saxon Dooms show little attempt if any to develop the form of action that later became trespass. This, briefly, is what Henry II put into his cauldron, and into his molds. Perhaps we should add also a suggestion of disseisin-the Saxon real$l_{a c}{ }^{18}$ and the suggestion of slander in the penalty for calling a man perjurer in the dwelling of another. ${ }^{10}$ What came of the process?

The first cases reported reveal three civil actions of tort of which one, trespass, in time absorbed the other two. They were the assize of novel disseisin, the assize of nuisance, and the action of trespass, or transgressio. All three in form contained words suggestive of violence, and all three were done contra pacem-against the king's peace. The words "with force and arms" had little significance, nor had the words injuste detinet any greater meaning, for a defendant sometimes denies the force and arms in debt upon an obligation. In disseisin the defendant injuste disseisavit, or injuste et sine judicio disseisavit, in the assize of nuisance the defendants injuste et sine judicio levaverunt quendam murum, in debt, the defendant injuste detinet.

Thus, in the reign of Henry II, the action of trespass, the whole common law, has become dynamic, for the reports of the following reign reveal three different forms of action, all of which might properly be designated trespasses; and if we regard the volume of cases in the plea rolls, there is no dearth of litigants. One characteristic of Saxon relief has remained, however, and is destined to remain in the common law for some centuries. That is the penalty that accompanies litigation. In the Saxon Dooms, the defendant paid six shillings to the plaintiff and twelve shillings to the king. In the common law, the

${ }^{17}$ Thorpe, op. cit. 85. Liebermann, op. cit. 69.

18 Thorpe, op. cit. rog.

"Thorpe, op. cit. 54. Liebermann, op. cit. 35. 
amercement is the almost inevitable result of a lawsuit. Whatever the relief administered, there is always some point in the case where one party or the other is prepared for an amercement or penalty. It is administered with fine impartiality and with no reference to the form of action. The plaintiff is amerced pro falso clamore in disseisin, ${ }^{20}$ pro injusta deforc in assisa ultime presentac' (unjust deforcement in darrein presentment) ${ }^{21}$ and pro injusta detentione in a plea of debt.22 No action is more or less penal, more or less noxal, because of the amercement. It is to be regarded more as a perquisite or profit of litigation than as an index of the degree to which the action was penal in its nature. Judged by this standard, debt and darrein presentment are as highly penal as trespass.

Thus, if we have no preliminary fundamental distinctions for the earliest forms of trespass, we have at least one characteristic common to all. It is not to be supposed that any one form of action had a power of assimilation that made it superior to the others. Distinctions were early formulated by which one action was made the vehicle for certain kinds of relief; for example, the matter of the right to real estate must be tried in the assize of novel disseisin; but the connotations of the three forms of trespass were not so clearly cut, that an authority as to the same kind of wrong might not be found in both the assize of nuisance and in trespass.

The notion that has somehow become inseparably connected with trespass is that it provided relief against deeds of violence, and therefore was accompanied by a suggestion of something unusually drastic in its administration of relief. This is founded upon a conception fundamentally wrong. The first litigation involving injuries due to violence was not pursued as a substitute for criminal processes. In the Saxon law, in the earliest times at least, there is very little suggestion of violence in the penalties. Even homicide is a thing to be paid for. It is not until the reign of King Alfred that the doctrine of an eye for an eye and a tooth for a tooth becomes a part of the law. The result of all litigation, as we have seen, was a money penalty. What, then, differentiated trespass from debt or contract? Was it that the courts afforded a civil remedy for a crime which could be enforced by imprisonment if necessary? This is absurd, because as we know, imprisonment for debt has only been abolished within a century. The theories that are spun about the action of trespass are children of a later growth

\footnotetext{
${ }^{20}$ Tempore Johannis, Placitorum Abbreviatio, 8r.

${ }^{n}$ M. 25 Hen. IIr, Placitorum Abbreviatio, IIo.

${ }^{2}$ M. 25 Hen. III, Placitorum Abbreviatio, Iro.
} 
and represent usually the jurist's attempt to satisfy his mind as to the reason upon which his decision is based. His real reason for the decision is to be found in history, and he decides in accordance with history even when he overrules a precedent.

The trespasses for which the first common-law writs were issued consisted of two that were aimed at specific offences generally connected with real estate. The third, trespass, was given from the first a connotation wide enough to have embraced both of the others, had there been any speculation as to legal remedies to open the eyes of judges and lawyers to that fact.

The action of novel disseisin was aimed at the forcible dispossession of a man from his freehold. It was a complete and thorough remedy; it restored the property of the owner, and awarded him damages for the detention, and the defendant paid a fine as well. ${ }^{23}$

The assize early. became the containing vessel for a fairly wide group of wrongs, and as litigation in the assize 'was frequent, it early developed principles and displayed a remarkable power of assimilation and sturdy growth that resisted until within the last few centuries the encroachment of trespass. Originally aimed at dispossession, it soon became a medium for trying title, and usurped to that extent the office of the writ of right. If we read Lilly's reports and his learned introduction we might possibly share his regret at the disuse of an action that admitted of so few delays, that afforded such prompt justice, and so efficient a remedy. So far as the decisions prior to the reign of Edward I are concerned, they disclose comparatively small variation in principle, but if the content of novel disseisin is known, we can more easily understand why the courts refused a remedy in trespass and referred it to novel disseisin. The application of the remedy was regulated in accordance with certain well-defined rules of inclusion and exclusion. It was a defense for the defendant to say that the plaintiff is his villein, ${ }^{24}$ and apparently it is an equally good defense that the plaintiff is a bastard. ${ }^{25}$ The writ did not lie between brother and sister. ${ }^{28}$ Nor did it apply to lands held in ancient demesne. ${ }^{27}$ The names of both parties are to be set forth in the writ. ${ }^{28}$ And the land and the quantity of land must

\footnotetext{
P. 7 and 8, Jolm, Placitorum Abbreviatio, 50; Tempore Johanris, Ibid., 76; M. 25 Hen. III, Ibid., II5.

"Tempore Regis Ricardi Primi, Placitorum Abbreviatio, II.

${ }^{2} 28$ Hen. III, Placitorum Abbreviatio.

* $\mathrm{H}$. John, Placitorum Abbreviatio, 38.

${ }^{27} 25$ Hen. III, Placitorum Abbreviatio, II7.

* M. 34 Edward I, Placitorum Abbreviatio, 259.
} 
be made certain before the assize is taken. ${ }^{20}$ It is not at all characteristic of the action of novel disseisin, that the action must be brought in the county in which the land is, for that objection apparently could be made in almost any common-law action. ${ }^{30}$ The assize includes actions for a variety of wrongs which, however, are uniform in principle. For example, the assize might be maintained for common of wood, ${ }^{31}$ for a common of piscary, ${ }^{32}$ for common of pasture. ${ }^{33}$ Finally, as a matter of practice, let us note that the plaintiff is liable to be fined if he claims a freehold when he has only a right of common. ${ }^{34}$

Evidently the basic principle of the relief in novel disseisin is that no one shall unjustly and without the judgment of a court deprive another of his property, but within the sphere of the action the remedy was complete and effective. It was understood that merely restoring his property to the plaintiff was not a complete remedy. He was injured by violence, perhaps; he was deprived of his property during a certain period, and the property was usually injured. There was something appealing in the extent to which self-help was permitted, in the extent to which the plaintiff within five days might gather his friends and forcibly eject the intruder, a feature apparently peculiar to this assize. As has been observed, this action resisted for centuries the encroachments of trespass in which respect it fared better than the assize of nuisance.

The assize of nuisance from its inception dealt with a class of wrongs that inevitably must have been recognized later as trespasses, and there seems little reason for one absorbing the other beyond the infinitely vaster connotation of trespass. Its justice was no speedier, in fact it was not so speedy as the relief afforded by the assize of novel disseisin. Many of the wrongs against which the assize of nuisance was directed were offences to which the cant phrase of equity, "irreparable injury," was aptly applied, so that such of its jurisdiction as was not absorbed by trespass fell into the capacious maw of equity.

From the beginining, the assize of nuisance follows a fairly consistent line of development, and the cases disclose a certain uniformity of relief. The court orders the restoration of the status quo, and such further relief as the situation calls for.

${ }^{20}$ P. 30, Edward I, Placitorum Abbreviatio, 245.

* P. 18, Edward I, Placitorum Abbreviatio, 282.

"Tempore Johannis, Placitorum Abbreviatio, 70.

Tempore Joharnis, Placitorum Abbreviatio, 5 I.

*P. 7 and 8 John, Placitorum Abbreviatio, 5I; M. 8 John, Ibid., 53;

Ibid., 68, 77, 8r. 44 Hen. III, Ibid., 146.

" T. I4 John, Placitorum Abbreviatio, 87. 
Thus, an assize of nuisance is brought against eight defendants because they unjustly and without legal right erected a certain wall in the free and common pasture of Foxcote, to the plaintiff's injury, etc. The jury say that the defendants erected the wall as alleged. Judgment that the wall be taken down, and all those who erected it, be in mercy. ${ }^{35}$

The remedy is complete, as judgment may be given not only for the removal of a wrongful structure but for damages as well..$^{36}$ If the assize is brought for the wrongful diversion of a water course, the judgment of the court is that the water be restored to its former course. ${ }^{37}$ The instances of the action are uniform in nature, for example, conducting a fair wrongfully, ${ }^{38}$ erecting a fence, ${ }^{39}$ obstructing a road, ${ }^{40}$ breaking a ditch. ${ }^{41}$

In all of these cases the issue is presented to the jury"Did the defendant unjustly, etc., obstruct the road," and if the jury answer "Quod abbas obstruxit viam illam" the court orders the abbot to open the road. Both of the assizes began with the same formula. The writ was either " $S_{i}$. . . injuste disseisavit" or "Si . . . injuste obstruxit." But the uniformity of litigation under the assize of nuisance is much more striking than in the case of novel disseisin. The connotation of nuisance was more limited even than that of novel disseisin.

The proceedings were the same in both assizes. The contrast between the two is instructive. The assize of novel disseisin is a remedy against the wrongful dispossession of the owner from his freehold. The assize of nuisance gives to trespass its basic principle of widest application, viz., sic tuo utere ut alienum non laedas, for the wrong to be redressed was the improper use of one's own property, the building of a house to the nuisance of a neighbor's freehold and the like.

For almost a century, between II94 A. D. and I285 A. D., these assizes held the field almost undisturbed against the action of trespass. It was not a very popular remedy until the reign of Henry III, and the cases are not numerous until much later. The words of the complaint generally follow the same formula, that the defendants "contra pacem domini Regis vi et armis intruserunt;" etc., and the relief awarded is usually damages."

${ }^{2}$ Tempore Regis Ricardi Primi, Placitorum Abbreviatio, 10.

* Assize 25 Hen. III, Placitorum Abbreviatio, Ir5.

${ }^{5} 25$ Hen. III, Placitorum Abbreviatio, I20, 12I; H. I2 E. I, Ibid., 205.

\%. I4 John, Placitorum Abbreviatio, 85.

Io Hen. III, Placitorum Abbreviatio, Io3.

- 8 Hen. III, Placitorum Abbreviatio, ror.

- 3 John, Placitorum Abbreviatio, 33.

Easter, 4 Hen. III, Bracton's N. B. pl. 85. 
The action of trespass naturally could not follow a consistent line of development by contrast with another form of action based upon a wrong diametrically opposite in principle. The clearer definition of trespass began when the principles of contract came to be understood. But that is a matter that had not yet been settled as late as 1388 A. D. in the reign of Richard II, if we may believe a dictum of Thirning, J., for he says that the issue of contract or not contract must be tried by the bishop. 43

Trespass, therefore, was defined at first only by contrast with other forms of tort or trespass, and possibly with debt. Words of force appear in the action of debt until a comparatively late period. For example, in an action of debt, the complaint is "injuste detinet" and the defendant in reply denies the tort and the force."

It is clear that no distinction can be made between trespass and any other form of action on the ground that trespass is more noxal or more highly penal than any other. The action is a civil action, and it is enforced precisely as are all of the other civil actions.

Trespass is not exclusively an action for damages as yet. In fact, it is doubtful if there was any action for damages as such until recourse to the action on the case became frequent. But the cases in. which damages are not awarded are comparatively few. If a man bring an action for the killing of his horse, or because of an assault, obviously in a civil action, he is seeking damages.

Trespass offers a much more coherent picture than any of the allied actions prior to the Statute of Westminster II. As in all other actions the law requires the plaintiff to be named in the writ.ts

The necessity of limiting an action having so broad a significance as trespass became apparent from the first. It was settled early that a matter of title or of right to possession could not be determined in an action of trespass. For example, the defendants were attached for entering the plaintiff's turbary, cutting turf, and illtreating his servants. The defendants replied that the turbary belonged to them and not to the plaintiff. It was held that since both parties claimed the seisin of the same tenements and this cannot be determined by the writ of trespass, but a writ of novel disseisin lies well in such a case, and like-

\footnotetext{
a. I2 R. II, Fitzherbert, Garde, I06. (This case is not very fully reported by Fitzherbert.)

«M. I2 R. II, Fitzherbert, Jurisdiction, 18.

- P. Edward I, Placitorum Abbreviatio, 272.
} 
wise both damages and the tenements can be recovered in novel disseisin, the writ in this case does not lie. ${ }^{48}$

A similar conclusion is reached in an action for cutting trees in which the defendant alleged that the trees were growing on his own land and not on the land of the plaintiff. The defendant says, "supra feodum et liberum tenementum suum" whence the conclusion of the court "liberum tenementum non potest per hoc breve de transgressione terminari."'17

Thus early was it determined that trespass did not lie to try the right to a freehold, nor to inquire concerning the title to a freehold. In both of these cases the court advises the plaintiff that he may, if he wish, purchase a writ of novel disseisin.

There are some few cases that bring us close to the action on the case. In I8 Henry III, the defendant is summoned to answer "quare vi et injuste" he uses a certain road and holds it beyond his land of Waleton, which he ought not to have, as it is said, and whence the complaint is that by this use, a plaintiff is injured and claims forty shillings damages. This question is left to the jury, as well as the question of title to the road. ${ }^{48}$

Evidently the law had no objection to trying the title to a road in trespass, although it refused to try the title to a freehold. Undoubtedly there is some confusion in the conception of the legal basis of redress. In an action for taking fishing nets and boats, it is alleged that the plaintiff was thus hindered from exercising his right of piscary. The judgment is that the nets must be returned, but there is no mention of damages."

The invasion of the plaintiff's liberty at Shornes, the breaking of his prison, and the removal and hanging of one of his prisoners by guards of the hundred of Shamel is the basis of an action as late as I7 Henry III. And the defense is that the hundred of Shamel has the right of infangenthef (taking of thieves) and utfangenthef (execution of thieves). ${ }^{30}$

The remaining cases of the period under discussion add little to the general principles derived from the cases thus far considered. The mere fact that trespass is brought for the taking of cattle is of little significance, nor is it instructive to know that the defendant pleads that the plaintiff is his villein. ${ }^{52}$

" H. 38 Hen. III, Placitorum, I42.

"M. I. Edward I, Placitorum Abbreviatio, 262.

- 18 Hen. III, Bracton's N. B. pl. 843.

- T. 15 Hen. III, Bracton's N. B. pl. 6r6.

- M. I7 Hen. III, Bracton's N. B. pl. 82r.

" 44 Hen. III, Placitoram Abbreviatio, I47. 
The actions follow a more or less uniform type, for example, trespass for false imprisonment; ${ }^{52}$ for breaking a ditch; ${ }^{63}$ for removing fishing poles; ${ }^{54}$ for removing grass; ${ }^{55}$ for taking wreckage $;^{58}$ for entering a liberty and burying a man without view $;^{58}$ invasion of a warren $;^{58}$ for assault $;^{58}$ for assault and beating ${ }^{80}$ for killing a horse. ${ }^{61}$

It would be an anomaly to find damages awarded in novel disseisin and nuisance and not in trespass. Damages were necessarily the basis of complaint in certain instances and where the wrong is the taking or killing of beasts; trespass is chosen as a remedy in order to obtain the value of the property taken or destroyed.

Thus, in 3 Edward I, Thomas Hegham sues Thomas de Leyburne and two others for taking and carrying away his cattle to the value of forty marks. The jury fixed the damages at nineteen marks. Afterward the court, being of opinion that the inquisition had not been carefully taken, issued a precept to the sheriff to summon the jury to inquire if the cattle of the plaintiff had been taken by precept of the said Thomas de Leyburne, and whether the plaintiff could have replevied them if he had desired. It was said that he could; the court held that the plaintiff had lost the cattle through his own negligence (quod ipse Thomas Hegham amisit averia sua negligencia sua propria) and that he should return the damages that had been paid to him. ${ }^{.2}$ In 9 Edward $I$, the abbot of Cern recovers ten pounds damages against the defendant for taking wreckage within his manor. ${ }^{83}$

Recalling now that trespass as a popular action is but in its infancy even in the reign of Edward I, let us observe that the action served two purposes. It served as a highly effective method of compelling restitution of property taken by force and it served equally well for the recovery of damages, where

${ }^{8}$ I5 Hen. III, Bracton's N. B. case 465. H. 9 Hen. III, Bracton's N. B. case ro41.

I5 Hen. III, Bracton's N. B. case 567 .

${ }^{8} \mathrm{H}$. I8 Hen. III, Bracton's N. B. case 835 .

${ }^{\mathrm{I}}$ Ig Hen. III, Bracton's N. B. case II2I; Io Hen. III, Ibid., case 1735.

M. 9 Edward I, Abbreviatio Placitorum, $20 \mathrm{r}$.

"Tempore Johannis, Abbreviatio Placitorum, 70.

${ }^{\infty 8}$ H. 38 Hen. III, Abbreviatio Placitorum, r4I ; T. 4 Edw. I, Ibid., 190;

M. 4 Edward I, Ibid., IgI; M. 9 Edward I, Ibid., 20I; H. ro Edw. I, Ibid., 202.

${ }^{50}$ M. 38 Hen. III, Ibid., I34.

T. To Edward I, Ibid., 274

a. 10 Edward I, Ibid., 274.

- Placitorum Abbreviatio, 265.

* Placitorum Abbreviatio, 201. 
the object taken could not be restored. It is equally certain that where the goods were taken under color of right and the appropriate remedy was replevin that trespass could not succeed. The writ did not always contain words indicating violence. In many cases the plaintiff merely complains and sets forth his damages. In others the formulæ, now second nature to the lawyer in a suit for trespass, are employed.

In almost all of the cases, some one, plaintiff or defendant, is amerced (in misericordia) but this is a matter entirely different from the damages (damna). The amercement is the king's indirect way of adding to his revenue. Surely it is a harsh decision in the cases of trespass considered above, that the plaintiff has sued in trespass, has miscontrued his wir, may sue in novei disseisin, but must make fine to the king, "pro falso clamore." The amercement, the penalty to the king, is the inevitable tax on litigation from which no one escapes, whether he sue in trespass, or even for breach of covenant. This may be verified by glancing at random through the cases in the Placitorum Abbreviatio. The penalty to the king had no relation to trespass, nor can any conclusion as to the penal nature of trespass be drawn from the fact that the penalty is imposed. It is imposed on any unsuccessful plaintiff "pro falso clamore,"-for having failed to make good his complaint. ${ }^{4}$

There is very little of a criminal nature in this action of trespass. The action is maintained without words of violence and with them, and amercement was likely to take place in an action brought by a simple complaint for taking wreckage, and to be omitted in a case filled with the rumblings of vi et armis, armed men, and destruction of manors. Trespass is administered as a civil remedy, and the vi et armis sometimes had significance and sometimes had not, much as is the case to-day.

The same assertion may be made as to damages. Trespass was sometimes brought for a specific sum stated in the complaint; sometimes to compel restitution of property, but it was not confined to either. Later, we shall find the courts refusing to give both property and damages, but that is another matter. As we have seen, the courts exercised a considerable power of controlling verdicts and this, too, grows to incredible bounds, the judges not only reducing verdicts but increasing them because they believe them insufficient. ${ }^{65}$

Again, outlawry has been suggested as one feature of trespass that made it unusually drastic in its operation, and therefore

\footnotetext{
"Bracton's N. B. pl. 208, 242.

- See note 63 , supra.
} 
a more popular remedy. But outlawry was a part of the entire common law. If a defendant persistently remained away from court after repeated summons, even in the action of debt, judgment was given against him by default, he was outlawed and his goods forfeited. His remedy then was to purchase a charter of pardon, and sue a scire facias against the plaintiff, in order to do what he should have done in the first place, viz., defend the action.

Apparently, then, the only virtue of the action of trespass was its extremely general or miscellaneous nature or its wider connotation. Why then its later popularity, and abnormal development?

The answer to this, apparently, is obvious, if the common law be considered from beginning to end. As has been observed, the earlier remedies were invented for instances, not for series of event. The actions of ael, bisael and cosinage are familiar examples. If you claimed of the seisin of your grandfather, you brought a writ of ael; if of the seisin of your great-grandfather, a writ of bisael; and if of some other relative, a writ of cosinage. Why should not all real actions to recover possession of land, or to vindicate the title to land, have been comprehended in an action of ejectment, or any of its synonyms? Simply because the law had not yet realized the similarity or identity of principle common to each. This, we believe, is the key to the development of the forms of action. From some hundred of different actions, existing at the time of Edward I, the common law has gradually selected two, contract and tort, which represent voluntary and involuntary action; consequences voluntarily assumed, and consequences thrust upon one. This is the only plausible reason for development of the action of trespass, the sole reason why trespass comprises so large a proportion of all modern litigation. It was the only action capable of holding all wrongs, of whatever description, just as assumpsit is the only action capable of embracing every manner of undertaking.

Nothing in the earlier cases of deceit could have warranted the supposition that they were trespasses; trespass was understood then. They are actions brought for false recoveries against plaintiffs, either by omitting to summon them, or by presenting fictitious affidavits, through fraud in the inquisition and the like. ${ }^{\circ 6}$

In the action brought to enforce the warranty in a fine, however, there is a reasonable approach to the modern action of

${ }^{*}$ T. 2 Henry III, Br. N. B. p1. 105. See also, Ibid., pl. I07; pl. I68; pl. 208; p1. 296; p1. 500 ; pl. 645 ; pl. Ii73; pl. Ir84; pl. 1629; pl. I747; 
deceit. It is unnecessary to observe, perhaps, that the fine is equivalent to a modern conveyance of record; with this difference, that the officers witnessing the transaction, instead of being notaries public, or some other official authorized to take acknowledgments, are judges of the court. In r225 A. D., 9 Henry III, Br. N. B. Pl. I69o, one Thomas, son of Ganfridus, was attached to reply to the widow Geve (Genevieve?) because of his failure to comply with a fine made at Westminster before the justices between Ganfridus, father of Thomas, whose heir he is, and Geve, for six shillings of rent, which Thomas refused to pay, because, says the plaintiff, her husband, Swanus, sold to Thomas her part of the chirograph (the deed or fine of the conveyance is tripartite-there are three originals written on one sheet of parchment, and when they are separated the cutting is made along a jagged line, the original or foot remaining with the court, and the other two copies going one to each party). The court having examined the foot of the fine, found that Ganfridus, father of the defendant and his heirs, held one messuage with the appurtenances in Coventry of Geva during her life, at a rental of six shillings. It was held that Geva should recover her seisin and that Thomas be in the mercy, he having defended the fine and the chirograph, and having falsely called a third person to the warranty. ${ }^{\circ 7}$

In this brief survey of the progress of trespass during six or seven hundred years, one fact surely is patent. There is no elemental fact or series of facts upon which redress is based. Possibly there is a theoretical breach of the king's peace in all trespasses, but that is merely a formality. Probably one who takes his neighbor's cattle knows what he is doing, and to that extent his trespass is an intentional wrong. But the cases discuss wrongs, and not whether they are intentional or not. In one instance they say the plaintiff has lost his cattle through his own negligence, indirectly acquitting the defendant of culpability. And since there are few or no indirect trespasses, it is fair to assume that trespass was aimed at intentional wrong, but this is no more a theory of trespass than of novel disseisin or of nuisance. It is true that these were really torts, but the law had not yet mentally connected them. As the cases show, the court will not grant relief in trespass that should have been sought in novel disseisin.

There is no suggestion in any of the cases as yet, of any approach to a legal standard of conduct. That is a product

pl. I924. See also, 5 Henry III, Br. N. B. pl. I946. (This is really a civil action for conspiracy, hardly a deceit.)

"Note the use of seisin. It is a right, not possession. The plaintiff really vindicates her right to collect six shillings of rent-her seisin. 
of a later day. The standard is purely objective. The law is made cognizant that a wrong has been committed-or since this is a prejudicial statement-becomes aware of an injury-it seeks the actor-the person actively contributing to the injury-it compels him to pay the sum ascertained as damages.

In scope, in range of actionable wrongs, trespass is wide enough. If your ownership of the thing injured is not denied, trespass affords a remedy. But it is not as yet an action for damages as such. The development of the action for damages and the rise of the action on the case belong to the succeeding period. 